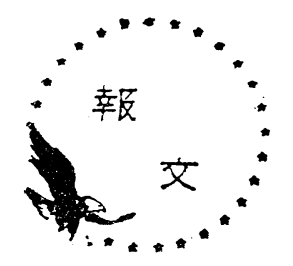

重油灰によるステンレス鋼の高温腐食

\section{I .まえがき}

近年火力発電用ボイラの燃料は, 石炭から 重油に移行する傾向にあり, 重油專焼ボイラ が各地に建設されて, 稼動中のものも年々增 加している。

重油専焼にともなつて発生する障害, とく に，バナジウムを含む重油灰による高温部伝 熱面の腐食は，わが国ではまだ経験されてい ないが，海外では発生したとの報告1)もあり，また， 腐食防止を目的としてボイラ内に添加剤吹込みがなさ れている例2 も報告されている。わが国においても， 重油専焼ボイラが増加し, 運転期間も長期にわたるに したがい，高温部腐食の起る可能について調查研究す る必要が生じてきた。

筆者は国内数ケ所の重油専焼ボイラ内から各伝熱面 上の付着物を採取し, 化学分析, 熱分析を行なつて諸 性状を比較検討するとともに，付着物による SUS 27 ステンレス鋼の高温における腐食試験を行なつて腐食 性之重油灰諸性状の関係を求めた。また， $\mathrm{V}_{2} \mathrm{O}_{5}-\mathrm{Na}_{2}$ $\mathrm{SO}_{4}$ 系混合物による腐食試験を行なつて重油灰の場合 と比較した。

これらの試験によつて, 重油灰によるステンレス鋼 の高温腐食について 2 のの知見を得たので報告する。

\section{II . 重油灰の付着状況}

現在稼動中の重油專焼ボイラ内の 4 ケ所のボイラに ついて，定期検查時に付着物の付着状況を観察すると とともに試料を採取した。各ボイラの仕様と試料採取 時までの運転期間などをTable 1 に示す。 4 ケ所のボ イラはすべて運転に大つてから初めての定期検查であ つた。

各発電所で使用した重油中のバナジウム, ナトリウ ム, イオウの含有量を各発電所について調べると, 分

$\begin{array}{lll}\text { バナジウム }\left(\mathrm{V}_{2} \mathrm{O}_{5}\right. & \text { として }) & 40 \sim 100 \mathrm{ppm} \\ \text { ナトリウム }\left(\mathrm{Na}_{2} \mathrm{O} \text { として }\right) & 20 \sim 40 \mathrm{ppm} \\ \text { イ カ ウ }(\mathrm{S} \text { として }) & 2.5 \sim 3.0 \%\end{array}$

Table 1 Data on power plant boilers

\begin{tabular}{|c|c|c|c|c|}
\hline Name of power station & A & B & $\mathrm{C}$ & $\mathrm{D}$ \\
\hline Capacity $(\operatorname{ton} / h)$ & 435 & 590 & 435 & 260 \\
\hline Pressure $\left(\mathrm{kg} / \mathrm{CH}^{2}\right)$ & 148 & 186 & 148 & 135 \\
\hline $\begin{array}{l}\text { Steam temperature, } \\
\text { superheater out } 1 \text { et, }{ }^{\circ} \mathrm{C} \\
\text { reheater outlet, }{ }^{\circ} \mathrm{C}\end{array}$ & $\begin{array}{l}541 \\
5 \div 1\end{array}$ & $\begin{array}{l}571 \\
544\end{array}$ & $\begin{array}{l}5+1 \\
5+1\end{array}$ & $\begin{array}{l}541 \\
541\end{array}$ \\
\hline Firing system & $\begin{array}{l}\text { Pressure- } \\
\text { firing }\end{array}$ & $\begin{array}{l}\text { Pressure- } \\
\text { firing }\end{array}$ & $\begin{array}{l}\text { Balance- } \\
\text { firing }\end{array}$ & $\begin{array}{l}\text { Pressure- } \\
\text { firing }\end{array}$ \\
\hline $\mathrm{O}_{2} \sigma_{c}$ in combustion gas & 2.0 & 2.0 & 2.5 & $1 \sim 1.2$ \\
\hline Date on sampling depusits & $3 i-6-2$ & $38-6-5$ & $5-6-14$ & $438-7-10$ \\
\hline Operating hours & imonths & 5300 hours & 21 months & 6165 hours \\
\hline
\end{tabular}

析值は大部分つぎの範囲内にあつた。

各発電所のボイラ内各伝熱面上の重油灰付着状況は つぎのよらであつた。各発熱所とも伝熱面温度の高い 2 次過熱器, 高温再熱器上の付着物は硬く融着してい たが，伝熱面温度が低くなるにしたがつて柔かくな り，蒸発管上の付着物は粉末状でさらさるしていた。 また, 重油灰の付着量を比較すると, C発電所では過 熱器, 再熱器の高温部に数 $\mathrm{mm}$ の厚みで付着していた が，D発電所では付着量が C 発電所の数分の 1 に過ぎ なかつた。これらのボイラで然焼した重油中の扊成分 量はほぼ同じであるから, 付着量の多少はボイラ構 造，燃焼条件，温度条件などの相違によるものである 亏。

\section{III. 付着物の組成}

4 ケ所の重油専燒ボイラ内の各伝熱面上から付着物 を採取し, 乳鉢で磨りつぶし, $110^{\circ} \mathrm{C} て ゙$ 乾燥後塩酸 (1: 1)で煮沸溶解し, 溶解成分についてバナジウム, ナトリウム, 硫酸基の定量分析を行なつた。それぞれ $\mathrm{V}_{2} \mathrm{O}_{5}, \mathrm{Na}_{2} \mathrm{O}, \mathrm{SO}_{3}$ として表示して分析值を乾燥試料 に対する\%として Table 2 に示した。 $\mathrm{V}_{2} \mathrm{O}_{5}, \mathrm{Na}_{2} \mathrm{O}$, $\mathrm{SO}_{3}$ の值を合計すると大部分 70 90\%を占めるので, これらを組合せて得られる化合物が付着物の主成分で あろら。合計が $60 \%$ 以下の例 ( $\mathrm{B}$ 発電所輻射過熱器 2 階および 4 階, D発電所再熱器中間部の 3 例）もあ るが，これは試料を塩酸に溶解するときの不溶解残渣 が 10〜20\% で他に比し大きかつたためである。それ 以外は不溶解残渣が $3 \%$ 以下であつた。 $\mathrm{V}_{2} \mathrm{O}_{5}$ の含有 
Table 2 Chemical analysis and melting points of oil ash deposits in oil-fired bailers

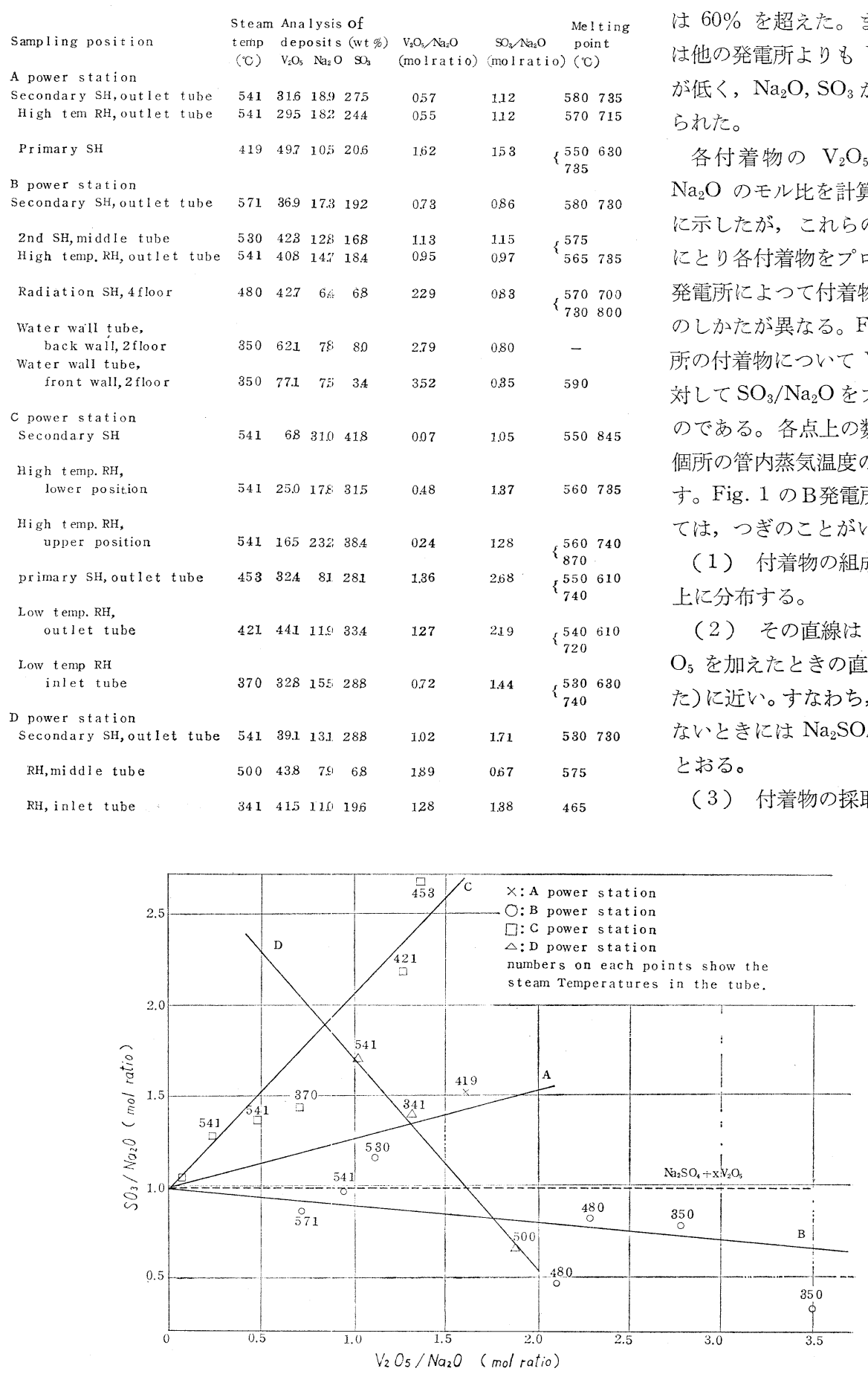

Fig. 1 Distribution on chemical compositions of

\section{deposits in each boilers}

率は多くの場合30〜50\%であるが， $\mathrm{B}$ 発電所の炉内蒸発管上の付着物で は 60\%を超えた。また，C発電所 は他の発電所よりも $\mathrm{V}_{2} \mathrm{O}_{5}$ の含有率 低く, $\mathrm{Na}_{2} \mathrm{O}, \mathrm{SO}_{3}$ が多、傾间がみ れた。

$\mathrm{V}_{2} \mathrm{O}_{5} / \mathrm{Na}_{2} \mathrm{O}, \quad \mathrm{SO}_{3} /$ 比計算して Table 2 所の付着物について $\mathrm{V}_{2} \mathrm{O}_{5} / \mathrm{Na}_{2} \mathrm{O}$ に てて $\mathrm{SO}_{3} / \mathrm{Na}_{2} \mathrm{O}$ をプロットしたも のである。各点上の数字は圾料採取 管内灰気温度の推定值を示 B発電所の直線につい は，つぎのことがいえる。

上に分布する。

和 直線(点線で示し に沂い。すなわち， $\mathrm{V}_{2} \mathrm{O}_{5}$ を含ま

（3）付着物の採取個所の温度方 
低くなるにしたがつて， $\mathrm{V}_{2} \mathrm{O}_{5} / \mathrm{Na}_{2} \mathrm{O}$ の比率，すなわ ち $\mathrm{V}_{2} \mathrm{O}_{5}$ の割合が増加する傾向がある。

$\mathrm{A}, \mathrm{C}, \mathrm{D}$ の各発電所の付着物も一直線上に分布卞 る傾向がある。A，C 発電所の直線は $\mathrm{Na}_{2} \mathrm{SO}_{4}$ に $(x$ $\left.\mathrm{V}_{2} \mathrm{O}_{5}+y \mathrm{SO}_{3}\right)$ を加えたときの直線に相当し, 勾配が 零より无犬き。Cが最も大きい。また， $\mathrm{A}, \mathrm{C}$ 発電 所も B 発電所と同様に, 一般的に付着物採取個所の温 度が低い方が $\mathrm{V}_{2} \mathrm{O}_{5} / \mathrm{Na}_{2} \mathrm{O}$ の比率が大きくなる傾向が みられた。 $\mathrm{A} ， \mathrm{~B}, \mathrm{C}$ の各発電所の三直線はすべて $\mathrm{V}_{2} \mathrm{O}_{5}$ を含まないときは $\mathrm{Na}_{2} \mathrm{SO}_{4}$ の組成の点に集る。 しかし，D発電所は Fig. 1 の上うに直線の勾配吕負 であつて， $\mathrm{Na}_{2} \mathrm{SO}_{4}$ の組成の点をとおらない。 $\mathrm{D}$ 発電 所だけが他の傾向と異なる理由としては，この発電所 のボイラ型式が他と異なり貫流型であること, 燃焼用 瀜剩空気率加最も低いこと, すなわち, 燃燒ガス中の 酸素濃度が最も低いことなどと関係があるのかも知れ ないが，分析值が少ないのでさらに検討を必要とす 石。

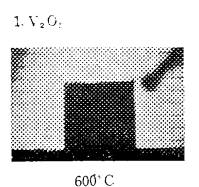

$600^{\circ} \mathrm{C}$

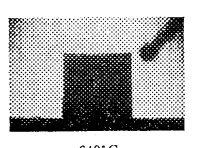

$640^{\circ} \mathrm{C}$
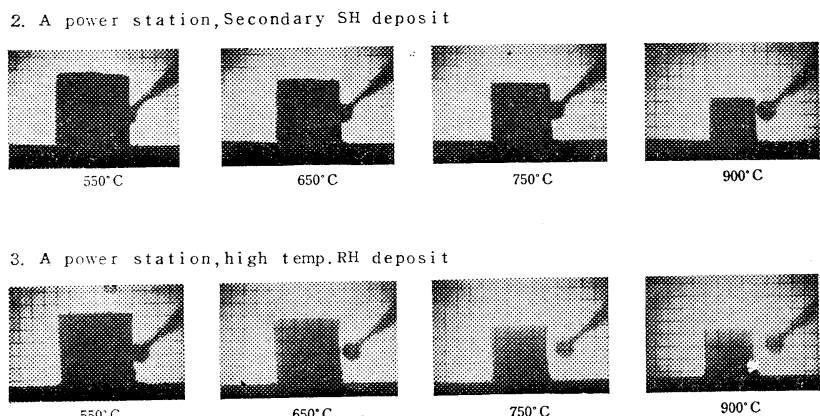

$750^{\circ} \mathrm{C}$

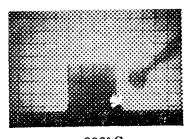

$900^{\circ} \mathrm{C}$

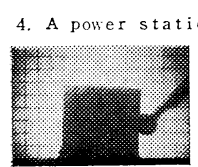

$500^{\circ} \mathrm{C}$

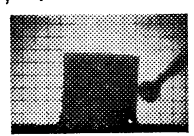

$570^{\circ} \mathrm{C}$

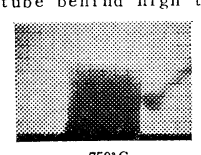

$750^{\circ} \mathrm{C}$

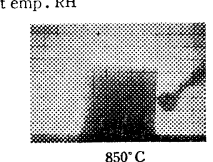

Fig. 2 Melting behaviors of $\mathrm{V}_{2} \mathrm{O}_{5}$ and deposits with the Leitz heating microscope.

\section{IV. 付着物の溶融性状}

1. 溶融性比の測定法

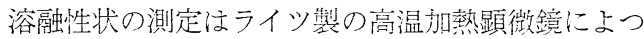
て行なつた。この装置は，電気炉內に入れた試料の颙 化溶融性状を連続的に測定することができる。この装 置の詳細は，別の報告 ${ }^{3}$ 文参照してほしい。

各発電所のボイラ内から採取した試料交充分に磨り つぶしてから，試料成型用ハンドプレスで $3 \mathrm{mmóx}$ $3 \mathrm{~mm}$ に成型し，アルミナ磁器慗の試料台に哉せ七電 気炉内の所定位置に插入する。温度文每分 $3 \sim 5^{\circ} \mathrm{C}$ の 昇温凍䓅になるよらに手動で可変抵抗器を調節する。

電気炬内の試料は温度上昇にともない試料の一部が

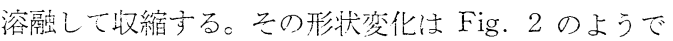
ある。Fig. 2 には $\mathrm{V}_{2} \mathrm{O}_{5}$ とボイラ付着物の 1 例とし てA発電所 2 次過熱器，高温再熱器上の付着物の打熱 による試料形状の变化を示した。 $\mathrm{V}_{2} \mathrm{O}_{5}$ のよ5に単一 物兴の場合には，その融点におい下急速に溶融して二 の形を消失子るが，重浊灰のよらに，種々の化合物が 混合している場合には形状相似のま圭徐 々に収縮する傾向がみられる。

各温度における試料の高さを闪眼をた は写真によつて観測し，試料塖入時の高 さを 100 として各温度のときの試料高さ を比較して表わし，試料高さと温度との 関係をグラフに画くとその試料の溶融出 線が得られる。

\section{2. 付着物の浴融曲線}

Table 2 の各試料の浴融性状を測定し て溶融曲線を得たがここではその 1 例 として $\mathrm{A}, \mathrm{B}$ 両発電所の 2 次過熱器, 高温再熱器上の付着物の溶融曲線をFig. 3,4 亿示した。C,D 两発電所より採取 した付着物についても, 2 次過熱器, 高 温再熱器上の付着物による溶融曲線はほ ぼ同様であつた。

Fig. 3，4 の各曲線はある温度で試料 の高さの急速な低下がみられるが，これ はその温度で溶融する成分を含むためで ある。図でわかるように，各付着物には 融点の異なる 2 3 の成分を含んでいる。

溶融曲線において, 下降する曲線の勾 配が 45 度を越える点の温度をもつて融点 と決め, 各付着物中の $900^{\circ} \mathrm{C}$ 以下の融点 の測定値を Table 2 に示した。

蒸気温度 $500^{\circ} \mathrm{C}$ 以上の伀熱面上江付着 


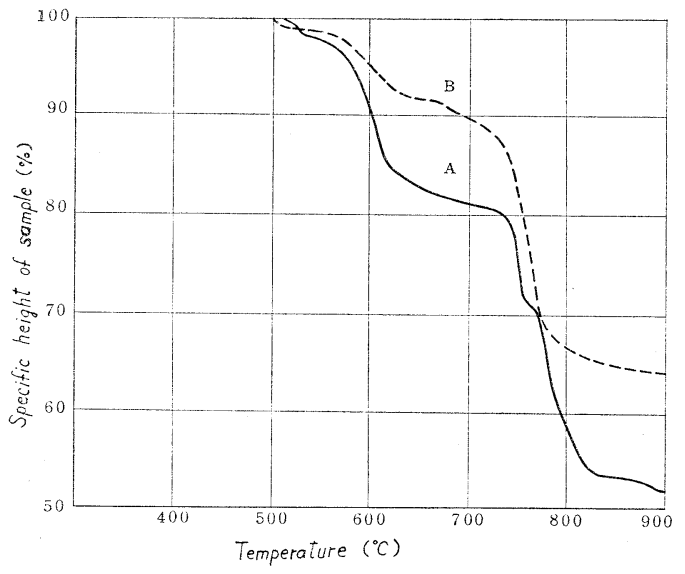

Fig. 3 Melting curves of the deposits on high temperature reheaters at $A$ and $B$ power stations

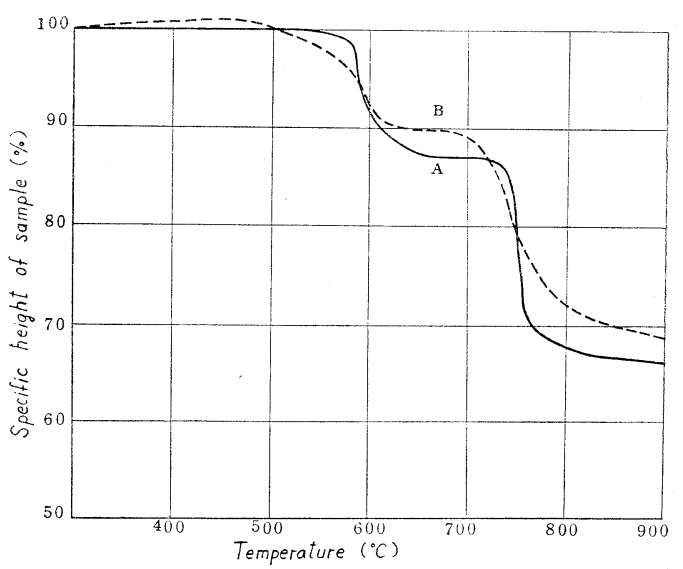

Fig. 4 Melting curves of the deposits on high temperatnre superheaters at $A$ and $B$ power stations
した重油灰の溶融曲線はほぼ同じ傾向を示し，約 570 ${ }^{\circ} \mathrm{C}$, 約 $730^{\circ} \mathrm{C}$ で溶融する成分を含んでいる。一方, 蒸 気温度 $500^{\circ} \mathrm{C}$ 以下の伝熱面上の付着物の溶融曲線はま ちまちであるが，最も低い溶融成分の融点は $570^{\circ} \mathrm{C}$ 以 下であつて，低融点成分の含有量も多くなる傾向がみ

\section{られた。}

3. $\mathrm{V}_{2} \mathrm{O}_{5}-\mathrm{Na}_{2} \mathrm{SO}_{4}$ 系混合物の溶融性状

重油専燒ボイラ内付着物中の $\mathrm{V}_{2} \mathrm{O}_{5}, \mathrm{Na}_{2} \mathrm{O}, \mathrm{SO}_{3} の$ 含有量を合計すると，付着物の $70 \sim 90 \%$ を占めるの で，比較のために， $\mathrm{V}_{2} \mathrm{O}_{5}-\mathrm{Na}_{2} \mathrm{SO}_{4}$ 系混合物の溶融曲 線を測定した。

$\mathrm{Na}_{2} \mathrm{SO}_{4}$ の割合がそれぞれ重量\%で 10\%，20\%，30 $\% ， 44 \% ， 60 \% ， 70 \%$ になるように $\mathrm{V}_{2} \mathrm{O}_{5}$ と混合し， $800^{\circ} \mathrm{C}$ に加熱溶融した後冷却微粉砕して試料とした。

$\mathrm{V}_{2} \mathrm{O}_{5}-\mathrm{Na}_{2} \mathrm{SO}_{4}$ 系混合物の溶融曲線は Fig. 5 のよ うである。Fig. 5 から求められる融点と, Cunningham ら ${ }^{4}$ が得た $\mathrm{V}_{2} \mathrm{O}_{5}-\mathrm{Na}_{2} \mathrm{SO}_{4}$ 系の状態図上の融点と は Table 3 のように $\mathrm{Na}_{2} \mathrm{SO}_{4}$ の割合が $60 \%$ 以下で はほぼ一致している。

Table 3 Comparison of melting points of $\mathrm{V}_{2} \mathrm{O}_{5}-\mathrm{Na}_{2} \mathrm{SO}_{4}$ mixtures by writer and literature ${ }^{1)}$

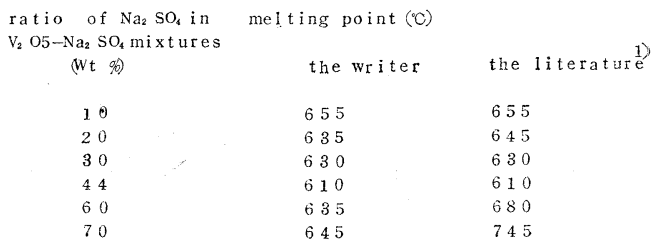

Fig. 5 Melting curves of $\mathrm{V}_{2} \mathrm{O}_{5-}$ $\mathrm{Na}_{2} \mathrm{SO}_{4}$ mixtures 


\section{V. 重油灰による高温腐食}

重油専菀ボイラ内に付着した重油灰による伝熱面の 腐食量莫実測することは困難なので，4ケ所の重油専 焼ボイラ内より採取した各伝熱面上の付着物による SUS 27 鋼の腐食試験を電気炉内で行ない，付着物の 諸性状, 試験温度などの腐食におよぼす影響を考察し た。去た， $\mathrm{V}_{2} \mathrm{O}_{5}-\mathrm{Na}_{2} \mathrm{SO}_{4}$ 系混合物による腐食試験を 同じ条件の下で行なつてボイラ内付着物による腐食よ 比較した。

1. 試験方法

1) 試料

(1) 試験 片

材 質: $18 \mathrm{Cr}-8 \mathrm{Ni}$ ステンこス鋼 (SUS 27)

寸 法: $12.9 \times 12.9 \times 2.9 \mathrm{~mm}$

(2) ルツボ

容 量 $15 \mathrm{cc}$ ，磁製 $\mathrm{C}$ 型ルツボ

(3) 重油灰の添加量

ボイラ内各伝熱面上に付着した重油灰ならびに $\mathrm{V}_{2} \mathrm{O}_{5}-\mathrm{Na}_{2} \mathrm{SO}_{4}$ 系混合物の添加量はすべて $3 \mathrm{~g}$ とした。

2) 試験装置と試験方法

ルツボ内に試験片と重油灰の規定量を科取して大 れ，白動温度調節計で一定温度に保持された電気マツ フル炉内に大れて所定時間後に取りだす。冷却後ルツ ボを割つて試験片を取りだし，スケールを除去して腐 食量老測定する。

3） スケール除去の方法

$\mathrm{NaOH}$ をニッケルルツボ内に入れて加熱し，約 360 ${ }^{\circ} \mathrm{C}$ で溶融させる。試験片を溶融 $\mathrm{NaOH}$ 内に浸漬し, 試験片をカソード，ルツボをアノードにして $300 \mathrm{~mA} /$ $\mathrm{cm}^{2}$ の電流密度で 3 分閒電解する。電解後, 直ちに試 験片を泠水中に入れて急泠する。試験片上のスケール をブラシで除去し，水洗する。

つぎに，インヒビターを添加した $5 \% \mathrm{HCl}$ 溶液中 に $80^{\circ} \mathrm{C}$ で 5 分間試験片を浸漬する。ブラシでスケー ルを除き, 水洗, 脱水, 乾燥して科量する。

2. 腐食試験結果

Table 2 にあげた 4 ケ所の重油専焼ボイラ内より採 取した付着物による腐食試験を温度 $600^{\circ} \mathrm{C}$ と $550^{\circ} \mathrm{C}$, 試験時間 200 時間の条件の下で行ない，Table 4 の結 果を得た。

腐食量と付着物の組成, 腐食量と試験温度との間に はつぎのような，ある傾向がみられた。

1) 腐食量と重油圧組成との関係

Fig. 6 は各付着物中の $\mathrm{V}_{2} \mathrm{O}_{5}$ の含有率上腐食量と の関係示す。垦ではボイラ内で最も管壁温度の高い
Table 4 Comparison on air corrosion of SUS 27 stainless steel in boiler eposits at $600^{\circ} \mathrm{C}$ and $550^{\circ} \mathrm{C}$ in 200 hours
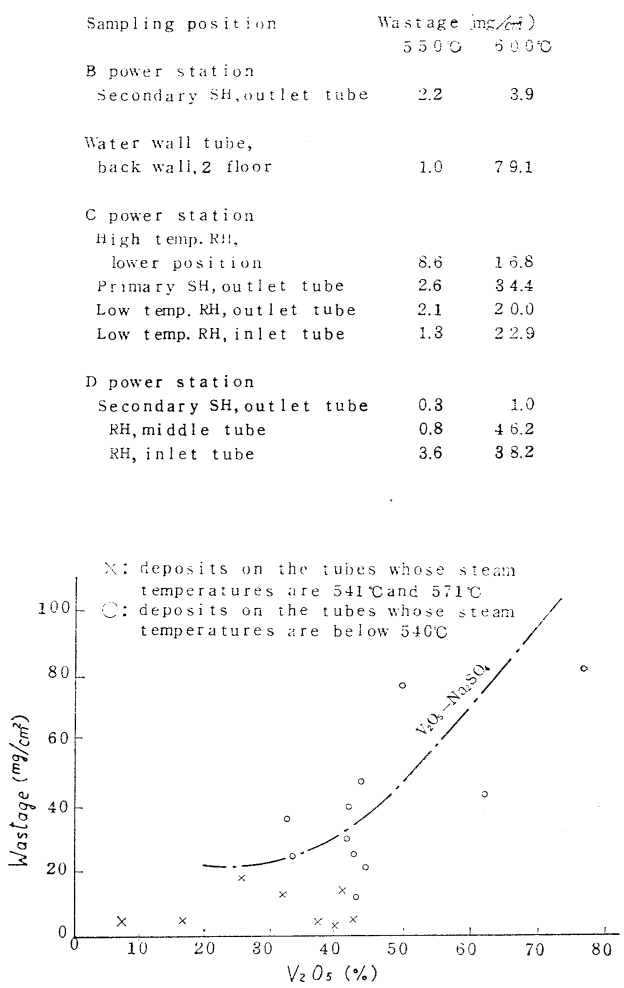

Fig. 6 Effect of $\mathrm{V}_{2} \mathrm{O}_{5}$ content on air corrosion of SUS 27 stainless steel in boiler deposit at $600^{\circ} \mathrm{C}$ in 200 hours

部分 (蒸気温度 $571^{\circ} \mathrm{C}$ と $541^{\circ} \mathrm{C}$ ), それ以外の部分とを 区別して示してある。また，参考のために $\mathrm{V}_{2} \mathrm{O}_{5}-\mathrm{Na}_{2}$ $\mathrm{SO}_{4}$ 系混合物による曲線も示した。 $\mathrm{V}_{2} \mathrm{O}_{5}-\mathrm{Na}_{2} \mathrm{SO}_{4}$ 系 混合物の配合比はつぎの 7 種類である。重量 \% $\mathrm{V}_{2} \mathrm{O}_{5} / \mathrm{Na}_{2} \mathrm{O}$ のモル比に換算するとつぎのようになる。

$\mathrm{Na}_{2} \mathrm{SO}_{4}$ の重量\%

$\begin{array}{lrrrrrc}10 & 20 & 30 & 44 & 60 & 70 & 80 \\ \mathrm{~V}_{2} \mathrm{O}_{5} / \mathrm{Na}_{2} \mathrm{O} & \text { のモル比 } \\ 7.00 & 3.17 & 1.87 \cdot 1.00 & 0.55 & 0.33 & 0.21\end{array}$

Fig. 6 ではつぎのことがいえる。

(1) $\mathrm{V}_{2} \mathrm{O}_{5}$ の含有率が多くなるにしたがつて，腐 食量が多くなる傾向がある。

（2）蒸気温度が最も高い過熱器管上の付着物はす り蒸気温度の低、管上の付着物上り腐食性が小さい。 
（3）蒸気温度が低い部分の付着物による腐食量 は, $\mathrm{V}_{2} \mathrm{O}_{5}-\mathrm{Na}_{2} \mathrm{SO}_{4}$ 系による腐食量に近いが，蒸気温 度の高い部分の付着物による噟食量は $\mathrm{V}_{2} \mathrm{O}_{5}-\mathrm{Na}_{2} \mathrm{SO}_{4}$ 系による腐食悬よりも小さい。

Fig. 7 に $\mathrm{V}_{2} \mathrm{O}_{5} / \mathrm{Na}_{2} \mathrm{O}$ のモル比と腐食量との関倸
を示した。Fig. 6 と同様に，図には蒸気温度の最も 高い部分の付着物とそれ以外とを区別して示し，参考 として $\mathrm{V}_{2} \mathrm{O}_{5}-\mathrm{Na}_{2} \mathrm{SO}_{4}$ 系混合物による腐食量の虽線も 示した。

Fig. 7 から Fig. 6 もと同樣なことがいえる。

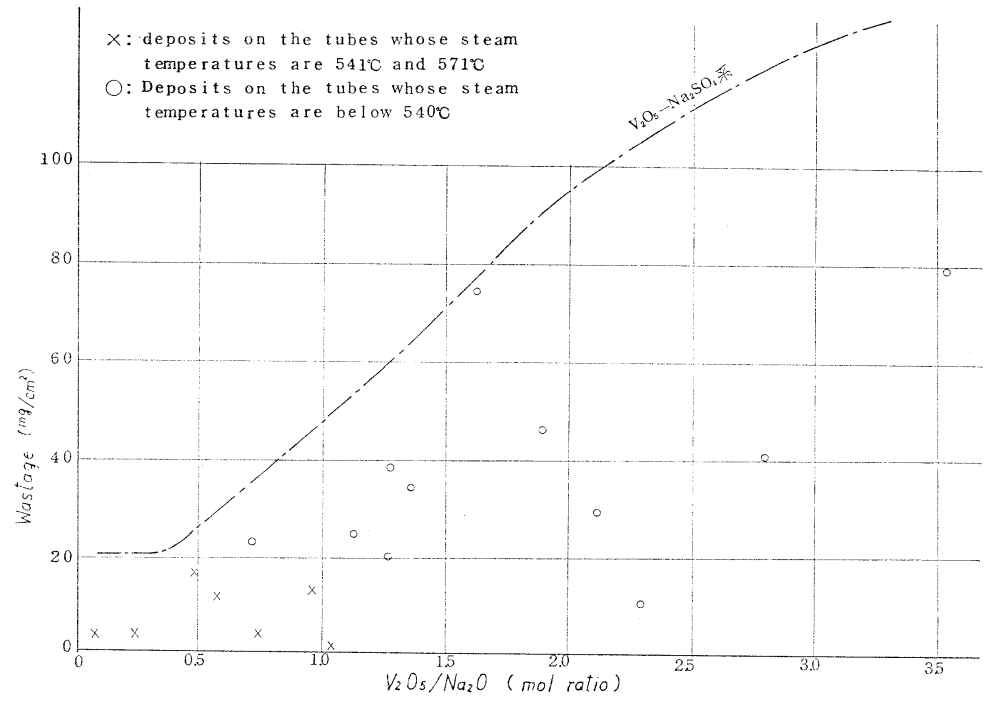

Fig. 7 Eifect of $\mathrm{V}_{2} \mathrm{O}_{5} / \mathrm{Na}_{2} \mathrm{O}$ ratio on air corrosion of SUS 27 stainless steel in boiler deposit at $600^{\circ} \mathrm{C}$ in 200 hours

(1) $\mathrm{V}_{2} \mathrm{O}_{5} / \mathrm{Na}_{2} \mathrm{O}$ の比が大きくなるにしたがつて, 腐食量が多くなる傾向がある。

（2）蒸全温度が最も高い過熱器管上の付着物は, より蒸気温度の低い管上の付着物より腐食性が小さ 以。

付着物による简食量が $\mathrm{V}_{2} \mathrm{O}_{5}-\mathrm{Na}_{2} \mathrm{SO}_{4}$ 系混合物によ る腐食量よりも小さい理由の一つとしては，付着物に は $\mathrm{V}_{2} \mathrm{O}_{5}, \mathrm{Na}_{2} \mathrm{O}, \mathrm{SO}_{3}$ 以外飞, $\mathrm{Fe}, \mathrm{Ni}, \mathrm{Mg}, \mathrm{Ca}, \mathrm{Si}$ などの元素の化合物を 10 ～30\% 含んでいること，そ のために，600 $\mathrm{C}$ の試験温度で溶融しない成分がある ことをあげることができる。

Fig. 6, 7 ではボイラ内で最も温度の高い伝熱面上 の付着物は, $\mathrm{V}_{2} \mathrm{O}_{5}$ の含有率または $\mathrm{V}_{2} \mathrm{O}_{5} / \mathrm{Na}_{2} \mathrm{O}$ の比 が小さく, 腐食量が $20 \mathrm{mg} / \mathrm{cm}^{2}$ 以下という限られた 範囲内に分布し, 温度の低、伝熱面上の付着物は $\mathrm{V}_{2} \mathrm{O}_{5}$ の含有率または $\mathrm{V}_{2} \mathrm{O}_{5} / \mathrm{Na}_{2} \mathrm{O}$ の比が大きく, 腐食量が 大き、範囲に分布する傾向がみられる。これらは温度 の高い伝熱面上には腐食性の小さい重油灰が付着する ことを意味する。このことが重油専焼ボイラに就いて 高温腐食による障害が経験されてない理由の一つであ
ろう。

2）腐食量と温度との関係

重油専焼ボイラの過熱蒸気温度は $571^{\circ} \mathrm{C}$ まは 541 ${ }^{\circ} \mathrm{C}$ 亿設計された例が多い。蒸気温度が $571^{\circ} \mathrm{C}$ の場合は 管壁温度が約 $600^{\circ} \mathrm{C}$ になり， $541^{\circ} \mathrm{C}$ の場合は約 $570^{\circ} \mathrm{C}$ になると推定される。

腐食試験は $600^{\circ} \mathrm{C}$ と $550^{\circ} \mathrm{C}$ で 200 時間行なつたが， $600^{\circ} \mathrm{C}$ は最高の管壁温度に近い温度, $550^{\circ} \mathrm{C}$ は管壁温 度を下げるときの影響をみる温度として選んだ。これ らの温度はまた，大部分の付着物の融点の上と下の温 度でもある。

（1）付着物採取個所の温度と腐食との関倸 付着物採取個所の管内蒸気温度の推定值と腐食量と の関係は Fig. 8 のよらである。

試験温度 $600^{\circ} \mathrm{C}$ における腐食量は蒸気温度が高い伝 熱面上の付着物の方が小さい傾向がみられ，蒸気温度 $541^{\circ} \mathrm{C}$ 以上の管上の付着物による $600^{\circ} \mathrm{C}$ における腐食 量は $20 \mathrm{mg} / \mathrm{cm}^{2}$ 以下である。温度の低い伝熱面上の 付着物では腐食量が $20 \mathrm{mg} / \mathrm{cm}^{2}$ を越える場合が多い が，試験温度を $550^{\circ} \mathrm{C}$ に下げれば $5 \mathrm{mg} / \mathrm{cm}^{2}$ 以下にな 


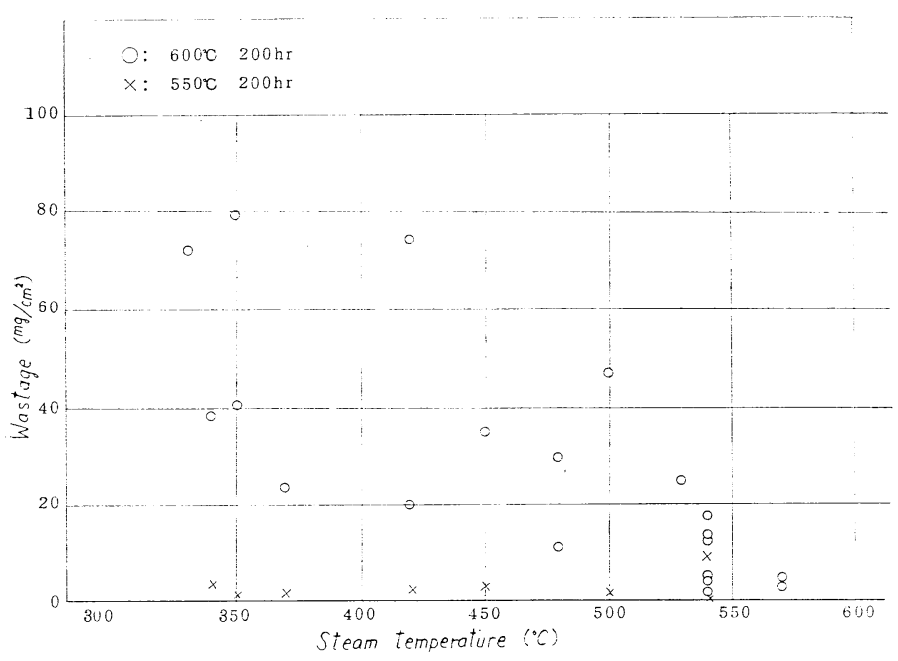

Fig. 8 Effect of presumed steam temperature in the sampling tube on air corrosion of SUS 27 stainless steel in boiler deposit at $600^{\circ} \mathrm{C}$ and $550^{\circ} \mathrm{C}$ in 200 hours
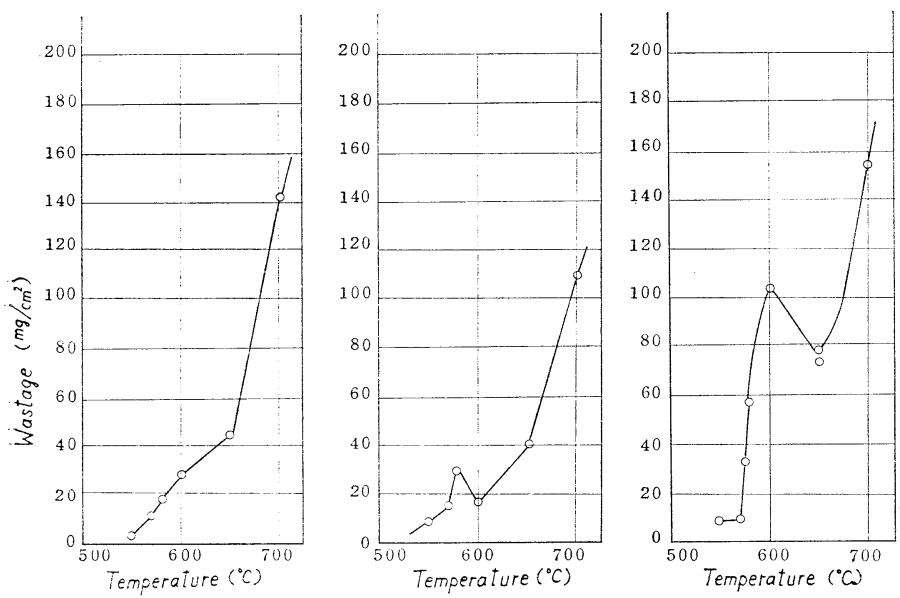

(a) B power station
Secondary SH out let
tube

(b) C power station $\mathrm{RH}$ lower position

(c) $\mathrm{V}_{2} \mathrm{O}_{5}-\mathrm{Na}_{2} \mathrm{SO}_{4}(30 \%)$ mixture

る。 $600^{\circ} \mathrm{C}$ と $550^{\circ} \mathrm{C}$ 污抄る腐食量 の比較を Table 4 に示す。

(2) 融点之の関保

付着物の融点は Table 2 にあけだ ように多くは $550^{\circ} \mathrm{C} 上 600^{\circ} \mathrm{C}$ の間に あるので，550市 における腐食圾験 では付着物は溶融しないでさらさら している。そのた动に550兄去け 当腐食量は少ない上考えら礼万の だ，重油疢による腐食はその融点以 上の温装で䦓題になる上㳊えたよい であるう。

(3) 腐食開始温度

Table 4のように, $600^{\circ} \mathrm{C}$ ¿ $550^{\circ} \mathrm{C}$

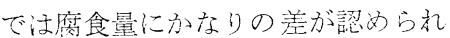
万場会があるので，数種の付着物に

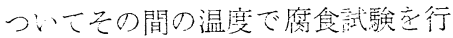
なつ下腐食開始温度を求的た。試験 結果の 2〜3 例を Fig. 9 に示した。 Fig. 9 には $\mathrm{V}_{2} \mathrm{O}_{5}-\mathrm{Na}_{2} \mathrm{SO}_{4}$ 混合物に よる試験結果も合せて示し，重油灰 による結果と比較した。Fig. 9 は 570〜 580 $\mathrm{C}$ から腐食が開始し，その 温度以上になると急に腐食量が増加 する傾问のあることを示している。 図の（b）と（c）では温度が高い 方が逆に腐食量が少なくなる場合の あることを示しているが，このよう な現象の起る理由はつぎの V. 3 で のベる。

3. 腐食量と時間との関係

$\mathrm{A}$ 発電所の 2 次過熱器出口管と 1 次過熱器上段の付着物について, $600^{\circ} \mathrm{C}$ と $700^{\circ} \mathrm{C}$ で腐食量と時閒の関 係を測定して Fig. 10 の結果を得 た。

2 次過熱器付着物による $700^{\circ} \mathrm{C} に$ おける腐食の様式は直線的であつて 50 時間を境にして腐食速度が変る。 $600^{\circ} \mathrm{C}$ では 2 次過熱器付着物と 1 次 過熱器付着物とでは腐食速度に大き な差がみられる。1 次過熱器付着物 は 200〜400 時間を境にして後の方 が腐食速度が遅い。200 時間までは 直線的であるが 400 時間以後が直線 


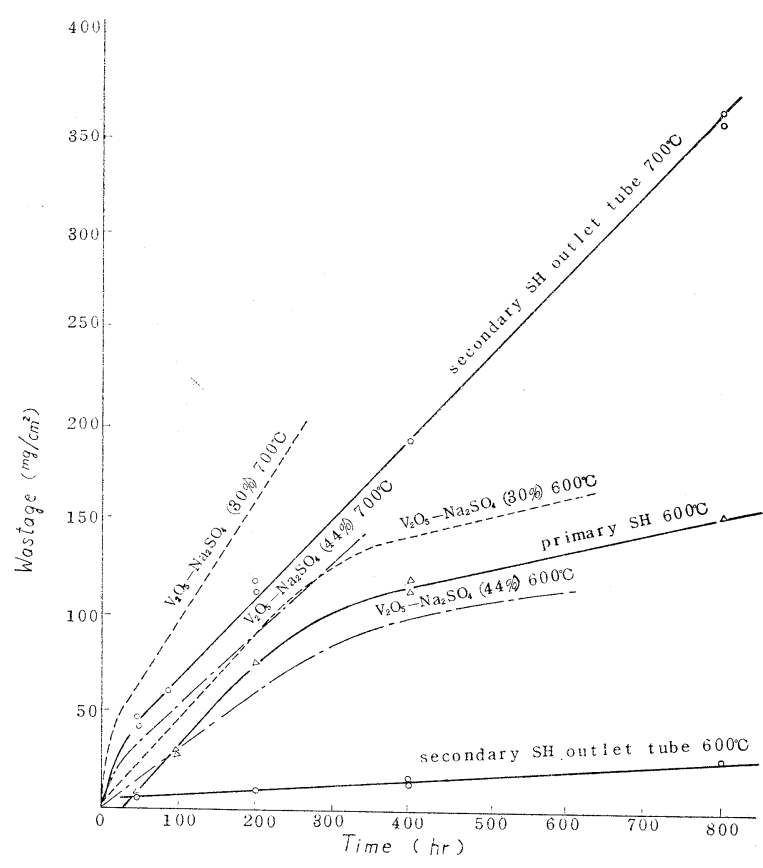

Fig. 10 Corrosion of SUS 27 stainless steel in various deposits at $600^{\circ} \mathrm{C}$ and $700^{\circ} \mathrm{C}$

的か放物線的かをこの試験結果からは決められな い。2 次過熱器付着物の場合は, Fig. 10 では直線的

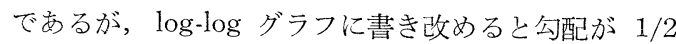
の直線になるので，放物線的であるとみなした方がよ いであろら。Fig. 10 には，また $\mathrm{V}_{2} \mathrm{O}_{5}-\mathrm{Na}_{2} \mathrm{SO}_{4}$ の混 合物による腐食量と時間との関係の一部を画いて重油 灰による曲線と比較した。双方の腐食傾向はよく類似 していて, $700^{\circ} \mathrm{C}$ に打ける 2 次過熱器付着物による曲 線と $600^{\circ} \mathrm{C}$ における 1 次過熱器付着物による曲線 は $\mathrm{V}_{2} \mathrm{O}_{5}-\mathrm{Na}_{2} \mathrm{SO}_{4}$ 系混合物における $\mathrm{Na}_{2} \mathrm{SO}_{4}$ を $30 \%$ と

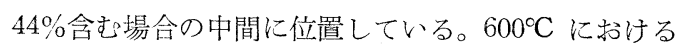
2 次過熱器付着物による曲線は $\mathrm{V}_{2} \mathrm{O}_{5}-\mathrm{Na}_{2} \mathrm{SO}_{4}$ 系によ る曲線よりはるかに低いが，これは $600^{\circ} \mathrm{C}$ までに溶融 する成分の含有量が少ないことによるのであろう。以 上の試験結果から，付着物の大部分が溶融するような 試験条件下では，腐食の様式が $\mathrm{V}_{2} \mathrm{O}_{5}-\mathrm{Na}_{2} \mathrm{SO}_{4}$ 系に類 似すると推定された。

Fig. 10 では $600^{\circ} \mathrm{C}$ と $700^{\circ} \mathrm{C}$ とで腐食の様式が異な るようなので, $\mathrm{Na}_{2} \mathrm{SO}_{4}$ を $30 \%$ 含む $\mathrm{V}_{2} \mathrm{O}_{5}-\mathrm{Na}_{2} \mathrm{SO}_{4}$ 系 混合物について $550 \sim 700^{\circ} \mathrm{C}$ の範囲内で腐食量と時間 との関係を求めた。Fig. 11 はその試験結果である。
Fig. 11 は温度によつて腐食の稼式が著しく変 ることを示している。 $550^{\circ} \mathrm{C}$ では $\mathrm{V}_{2} \mathrm{O}_{5}-\mathrm{Na}_{2} \mathrm{SO}_{4}$ 系混合物は溶融しないので腐食速度はきわめて遅 く, 400 時閒まで直線的である。 $575^{\circ} \mathrm{C}$ では初期， の腐食速度は遅いが，腐食の進行にともなつて腐 食速度も早くなるという, 促進酸化的傾向を示 す。 $600^{\circ} \mathrm{C}$ では 200 時間までは值線的であるが, それ以後では次第に腐食速度が遅くなる。 $650^{\circ} \mathrm{C}$ では初期の腐食速度は $600^{\circ} \mathrm{C} よ り$ 早いが，50時間 以降次第に腐食速度が幄くなるので，150時閒以 降は $600^{\circ} \mathrm{C}$ よも腐食量が少ない。しかし, 温度 が $700^{\circ} \mathrm{C}$ に上昇すると, 初期, 後期とも腐食速度 が著しく早い。

以上のように, 温度によつて腐食の様式が変り 各曲線が交差する場合も出てくるので, 各温度に. おける一定時間の腐食量を比較すると，Fig. 9 の ように, $650^{\circ} \mathrm{C}$ における腐食量がそれよりも温度 の低い $600^{\circ} \mathrm{C}$ における腐食量よりも少ないという 特異な現象となつて現われることになる。

Fig. 12 に Fig. 11 の腐食試験後の試験片の 1 例として，200 時間後の各温度における腐食試験。 片の外観を示した。各温度によつて外観がかなり 相違することから，腐食機構が同一でないことを 想像することができよう。

\section{4. 腐食量の推定}

ボイラ内で重油灰による高温腐食が最も問題になる. のは過熱器, 再熱器の最高温部であつて, その温度は 約 $600^{\circ} \mathrm{C}$ であろう。この部分に付着する重油灰による $600^{\circ} \mathrm{C}$ に扔ける腐食の様式は Fig. 10 のように放物線: になるものと推定され，600 200 時間の腐食量は Fig. 7 にメ印で示したように $20 \mathrm{mg} / \mathrm{cm}^{2}$ 以下のこと が多い。腐食の様式が放物線として 1 年間の腐食量を 推定すると, $0.2 \mathrm{~mm} /$ 年 以下となる。

温度の比較的低い伝熱面 ( 1 次過熱器, 再熱器低温. 部, 蒸発管など) 上の付着物による $600^{\circ} \mathrm{C}$ における腐。 食量は 200 時間で $20 \mathrm{mg} / \mathrm{cm}^{2}$ 以上の場合が多いが, $550^{\circ} \mathrm{C}$ では $5 \mathrm{mg} / \mathrm{cm}^{2}$ 以下になる。これらの伝熱面の, 温度は $550^{\circ} \mathrm{C}$ 以下なので, $550^{\circ} \mathrm{C}$ に扮ける腐食量を基: にして 1 年閒の腐食量を放物線として計算すると 0.05 , $\mathrm{mm}$ 以下になる。

この推定はつぎのよらな実験条件による結果なの でホホイラ内の諸条件下では若干異なるであろう。

試験片材質：SUS 27

試 験 法:ルツボ法

雲 国 気: 静止した空気中 


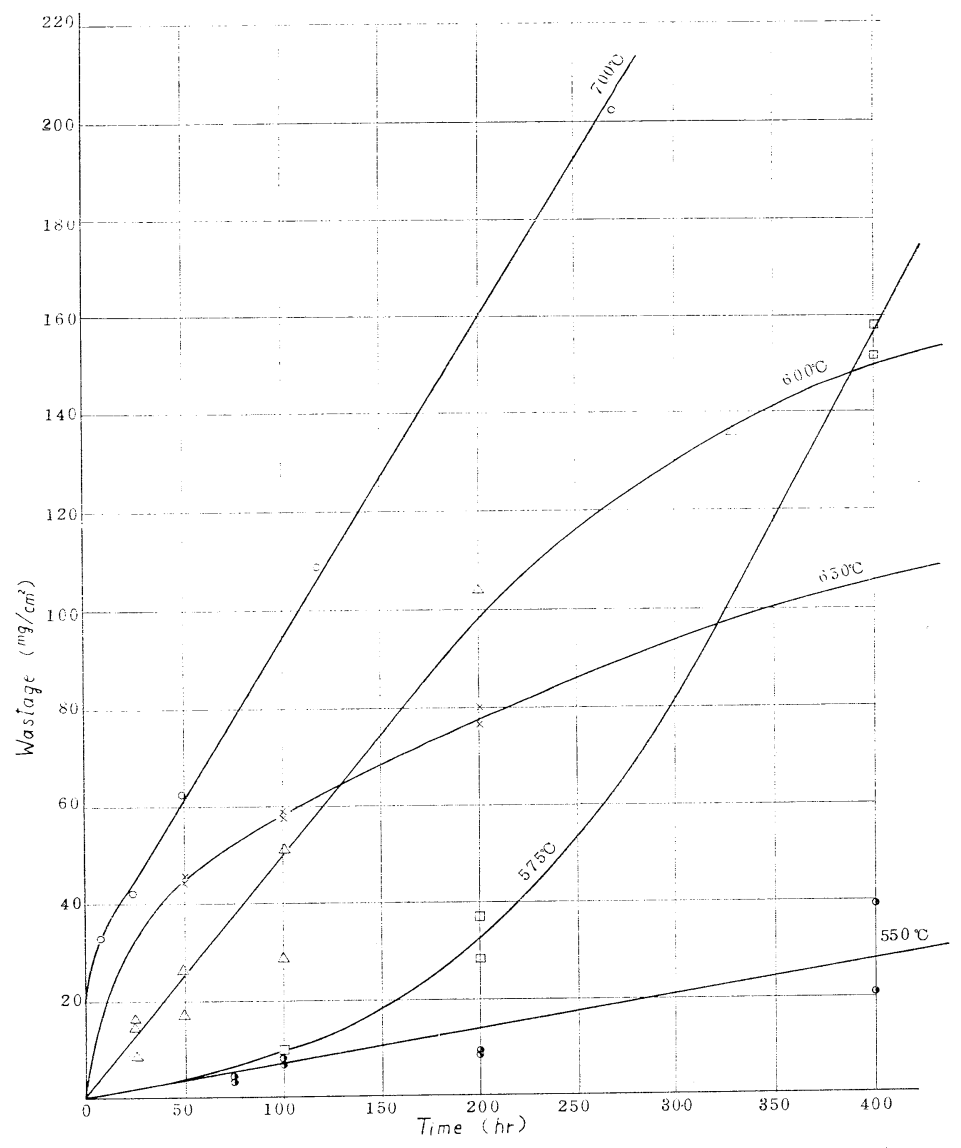

Fig. 11 Coxrosion of SUS 27 stainless steel in $70 \% \quad \mathbf{V}_{2} \mathbf{O}_{5}+30 \%$ $\mathrm{Na}_{2} \mathrm{SO}_{4}$ mixture at various temperatures

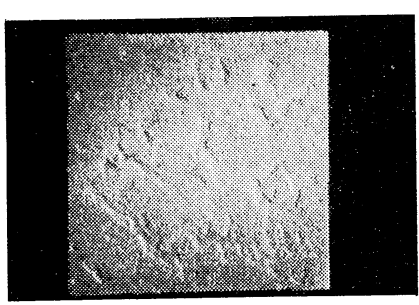

$550^{\circ} \mathrm{C}$

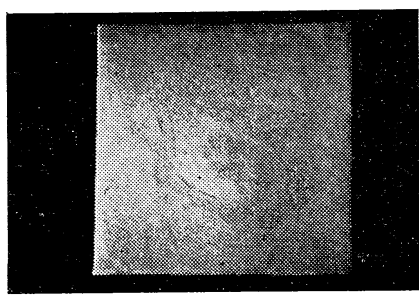

$650^{\circ} \mathrm{C}$

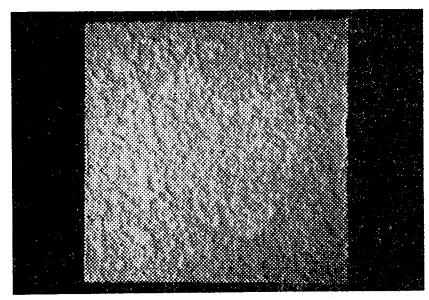

$575^{\circ} \mathrm{C}$

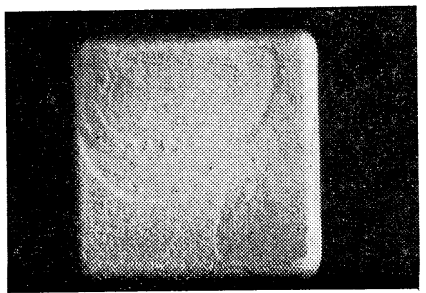

$700^{\circ} \mathrm{C}$

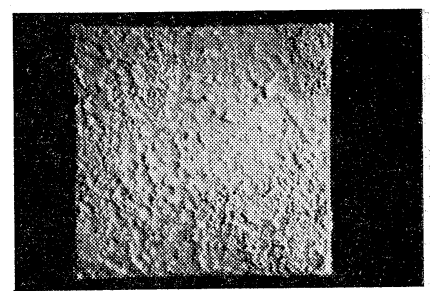

$600^{\circ} \mathrm{C}$

Fig. 12 Appearance of samples after air corrosion in $70 \%$ $\mathbf{V}_{2} \mathbf{O}_{5}+30 \% \quad \mathbf{N a}_{2} \mathbf{S O}_{4}$ mixture at various temperatures in: 200 hours 
蓔貫流なし

Alexander $5^{5)}$ はボイラ内の過熱器管に 7 種の材質 の銅管を溶接し，20,000時間の腐食試験を行なつた。 この間, 試験片の温度が593〜 621 $\mathrm{C}$ 期間が8, 000時間 で㟧つた。試験後の管の腐食量は $\mathrm{FCB}(\mathrm{T})$ 鋼 $(18 \%$ $\mathrm{Cr} 12 \% \mathrm{Ni} 1 \% \mathrm{Nb}$ 銅) で $0.1 \sim 0.25 \mathrm{~mm}$ であつた。

このAlexander らの結果は筆者功実験室内の腐食 試験から推定した 1 年間の腐食量とほぼ一致している ので，わが国におうる重油專焼ボイラ内の過熱器管の 噟食量泣この程度に起り得るのではないかと考えてい る。

Fig. 10 では, $575^{\circ} \mathrm{C}$ における $\mathrm{V}_{2} \mathrm{O}_{5}-\mathrm{Na}_{2} \mathrm{SO}_{4}$ 系の 合成灰による腐食の柡烒が促進酸化的傾向のあること を示しているので，実際のボイラ内でこのよらな様式 の腐食が起る可能性があるかどらかが問題になる。し かし，それについては，2 次過熱器付着物中には $60^{\circ}$ ${ }^{\circ} \mathrm{C}$ 前後の温度で溶融する成分の含有量が少ないので, このよらな腐食の起る可能性はないと考えている。各 所のボイラから採取した 2 次過熱器管上の付着物に ついて，550〜 650 Cの温度範囲で腐食試験した経験か らも促進酸化的腐食の起つた例はなかつた。

\section{VI. 亡 め}

4 ケ所の重油専焼ボイラ内に付着した重油灭の化学 成分の分析, 溶融性状の測定, 腐食試験などを行な い，付着物の性状と腐食性との関係をしらべてつぎの よらな結果を得た。

（1）ボイラ内に付着した重油灰はV， $\mathrm{Na}, \mathrm{S}$ の含 有量が最も多く, $\mathrm{V}_{2} \mathrm{O}_{5}, \mathrm{Na}_{2} \mathrm{O}, \mathrm{SO}_{3}$ を合計すると重 油灰の 70〜90\% を占める。

（2）温度の低い伝熱面に付着した重油灰の方が $\mathrm{V}_{2} \mathrm{O}_{5}$ の含有率と $\mathrm{V}_{2} \mathrm{O}_{5} / \mathrm{Na}_{2} \mathrm{O}$ の比が大きい傾向がある。

（3）付着物の組成は各発電所によつて特徴があ る。すなわち，各付着物の $\mathrm{SO}_{3} / \mathrm{Na}_{2} \mathrm{O}$ と $\mathrm{V}_{2} \mathrm{O}_{5} / \mathrm{Na}_{2} \mathrm{O}$ の比を図上にプロットすると直線関係にあり，発電所 によつて直線の勾配が異なる。

（4）蒸気温度 $500^{\circ} \mathrm{C}$ 以上の伝熱面上の付着物は,共 つうして約 $570^{\circ} \mathrm{C}$ で溶融する低融点成分を含んでいる。

(5) 重油灰中の $\mathrm{V}_{2} \mathrm{O}_{5}$ の割合，または $\mathrm{V}_{2} \mathrm{O}_{5} / \mathrm{Na}_{2} \mathrm{O}$ の比が大きい方が腐食性が大きい。

（6）最高温の伝熱面 (2 次過熱器, 高温再熱器) 上の付着物の腐食性は小さい。比較的温度の低い伝熱 面上の付着物の腐食性は大きいが，管壁温度が低いの で実際上腐食の問題は起らない。

(7) 重油灰の融点以上の温度 $\left(600^{\circ} \mathrm{C}\right)$ では食が起 石可能性があるが，融点以下の温度 $\left(550^{\circ} \mathrm{C}\right.$ ，多くの
場合融点以下になる）では腐食量はきわ方て少ない。

（8）重油灰による高温腐食の開始する温度は 570 $\sim 580^{\circ} \mathrm{C}$ である。

（9）重油灰が大部分溶融する温度下での重油灰に よる腐食傾向は， $\mathrm{V}_{2} \mathrm{O}_{5}-\mathrm{Na}_{2} \mathrm{SO}_{4}$ 系による腐食傾向と 類似するる。

（10）ボイラ內の最高温伝熱面上の付着物による SUS 27 鋼の $600^{\circ} \mathrm{C}$, 空気中における 1 年閒の腐食量 は $0,2 \mathrm{~mm}$ 以下と推定される。

以上のような試験結果から, 重油専焼ボイラでは, ボイラの諸条件（蒸気温度など）または使用重油の性 状（バナジウム含有量など）が現状より大きく変らな い限り，重油灰によつて犬きな障害の起る可能性は少 ないよらである。しかし，最近比較的バナジウム含有 量の多いイラン系ガチサラン原油の翰入量が増加する 傾向にあるので， $\mathrm{V}_{2} \mathrm{O}_{5} / \mathrm{Na}_{2} \mathrm{O}$ の比の大きい重油扊が 付着し, 腐食量も多くなる可能性も考えられる。各重 油専焼ボイラの高温腐食に関しては今後とも充分に注 意する必要がある。

\section{VII.あとがき}

この報告書は重油燃焼ボイラ内から付着物老採取 し，化学分析，溶融試験を行ならとともに，付着物に よる腐食試験を電気炉内で行なつて，付着物の性状と 腐食性との閒の関係，腐食におよぼす温度の影響など についてのべたものである。今後ますます重油燃焼ボ イラ多多数建設される傾向にあるので，この報告書が 高温腐食対策を考える上に少しでも参考になれば幸い に思う。

終りに，この研究を行ならに当り終始御懇切な御指 導と御助言を戴いた当所織田健一博士，大塚唯男博士 に感謝の意を表します。また，付着物試料を採取する に当り，各発電所の方々に種宣をはかつて戴いたこ と，試料採取に際しては下田修氏，矢田部照夫氏の御 協力を戴いたことなどについて厚く感謝します。

\section{文献}

1) A. M. Hall, D. Douglass, and J. H. Jackson, Trans. ASME, 75, 1037〜1049 (1953)

2)重油ボイラにおける障害および対策について，火 力発電技術協会, (昭 37)

3) 大塚唯男, 矢田部照夫：電力中研・技術研究所報 告 (化学, 57009)

4) G. W. Cunningham, A, Brasunas, Corrosion, 12, 389t 405t (1956)

5) P. A. Alexander, R. A. Marsden, J. M. Nelson-Allen, W. A. Stewart, J. Inst. Fuel, $37,59 \sim 69$ (1964) 


\title{
High Temperature Oxidation of Stainless Steel by Fuel Oil Ash
}

\author{
by Yoshimi Ishihara \\ (Central Research Institute of Electric Power Industry)
}

SYNOPSIS :- Laboratory tests have been made, on SUS 27 stainless steel, to study the corrosive effect, at temperaturs of $550 \sim 700^{\circ} \mathrm{C}$, of oil ash deposits in 4 oil fired boilers. The chemical constituents and the meltingpoints of the deposits had been also. determined.

Conclusions after testing were as follows:

(a) The deposits having higher $\mathrm{V}_{2} \mathrm{O}_{5} / \mathrm{Na}_{2} \mathrm{O}$ ratio were more corrosive.

(b) In many cases deposits contained a component melting at about $570^{\circ} \mathrm{C}$.

(c) All of the deposits were less corrosive at bellow $570^{\circ} \mathrm{C}$.

(d) The corrosive effect of the deposits on superheaters, whose steam temperaturs were $540^{\circ} \mathrm{C}$ and $570^{\circ} \mathrm{C}$, was lowest.

(e) The wastage of SUS 27 stainless steel in one year by air oxidation in the deposits on the secondary superheaters, at $600^{\circ} \mathrm{C}$, was estimated at below $0.2 \mathrm{~mm}$.

\section{ディーゼル発電機対燃料電池}

安価なメタノールを燃料とする実用的な燃料電池が英国のシエル研究会社で展示された。

この燃料電池ニニットは $5 \mathrm{~kW}$ の出力有し, 乗物に十分塔載できる大きさである。燃料のメタノール 汇石油の誘導体で, 1 gal 当り 2 シリング 3 ペンスと安価である。しかしメタノールは液体として直接燃 焼するのではなく，白金の触媒のもとに蒸気と反応して我素に変換されてから燃焼する。たとえ高価な 白金孝触媒に使うとしても，高価な有毒性のヒドラジンよりはメタノールの方がより実用的である。

この然料電池の屋外試験には, カンゴというコンクリートを破挽する電気ハンマーの電源が選ばれた 同出力のディーゼル発電機よりも，静かさ，保守，碩丈さの点で優れていることが立証された。この装 置には連続 12 時間分の燃料を積むことができる。

Elec. Rev. 175877 (1964) 